\title{
CARTAS
}

\section{Prezados Doutores,}

Nessa semana recebi o exemplar do nosso artigo intitulado "Simplificando a obtenção e utilização de imagens digitais", e gostaria de agradecer e parabenizar toda a equipe da Dental Press pela qualidade do material.

Atualmente tem sido muito utilizado o termo "excelência" em Ortodontia e acredito que esse é o melhor termo para qualificar a Dental Press, parabéns a todos.

Aproveito também, a oportunidade, para agradecer ao Ronis Furquim por toda a assistência durante a etapa final do trabalho,

André Wilson Machado - awmachado@bol.com.br
Caro Senhor Editor Dr. Adilson Ramos e demais componentes da equipe da Revista Dental Press

Venho parabenizá-los pela edição de número 4 do volume 8 da Revista Dental Press, e também agradecer a valorização do meu trabalho publicado neste número juntamente com o Professor Jorge Abrão. A qualidade editorial da revista está ótima e a apresentação da publicação da nossa pesquisa está impecável. Isto nos engrandece e estimula para novas empreitadas no intuito de melhorarmos ainda mais o material que enviamos para a apreciação futura deste corpo editorial.

\section{Paulo Cezar R. Ogeda - ogeda@fo.usp.br}

ABNT NBR 5601, por não ter sido detectado molibdênio, cobre, alumínio e nitrogênio.

4) Não foi citada a análise da presença de molibdênio em nenhum caso - que é um dado importante.

5) O teor de enxofre no braquete Morelli está muito acima do real uma vez que o equipamento utilizado para esta análise foi o espectofotômetro, quando o mais preciso seria por combustão/infravermelho.

6) Os autores não demonstraram as microestruturas dos braquetes de nenhuma marca, de modo a possibilitar a correlação entre as propriedades mecânicas e a composição química.

7) Os autores citam que a dureza é importante, motivados pela reciclagem de braquetes, o que constitui uma prática de trabalho negativa do ponto de vista sanitário e ineficaz, considerando o custo da mão de obra comparado aos preços dos braquetes.

Temos auxiliado inúmeros trabalhos acadêmicos com informações técnicas através de nosso laboratório de aplicações além do fornecimento de produtos da linha Morelli para desenvolver suas teses. Colocamo-nos também à disposição dos prezados autores para quaisquer orientações a respeito do tema.

\section{José Damian Alix Fernandez}

Departamento Comercial

josedamianalixfernandez@morelli.com.br 